\title{
Like phoenix from the ashes: How modern baleen whales arose from a fossil "dark age"
}

Felix G. Marx, Erich M.G. Fitzgerald, and R. Ewan Fordyce

Acta Palaeontologica Polonica 64 (2), 2019: 231-238 doi:https://doi.org/10.4202/app.00575.2018

The evolution of baleen whales (Mysticeti), the largest animals on Earth, was punctuated by a pivotal turnover event. Following their emergence around 36 million years (Ma), mysticetes diversified into a disparate range of toothed and toothless species until $23 \mathrm{Ma}$, but then nearly vanished from the global fossil record for the next five million years. Following this early Miocene "dark age", toothless mysticetes spectacularly reappeared around 18-17 Ma, whereas toothed mysticetes had gone entirely extinct. Here, we suggest that this turnover event reflects a change in mysticete habitat occupancy. Using the well-sampled record of Australasia as a case study, we show that Oligocene pre-"dark age" mysticetes formed distinct coastal and offshore assemblages, dominated by small (2-4 m), ecologically disparate toothed species, and larger $(5-6 \mathrm{~m})$ toothless filter feeders, respectively. Environmental change around the Oligocene-Miocene boundary led to the decline of the endemic coastal assemblages, leaving nearshore deposits virtually devoid of mysticetes. Filter feeders persisted offshore and subsequently re-invaded coastal habitats during the mid-Miocene Climatic Optimum, thus establishing the modern, cosmopolitan mysticete fauna.

Key words: Mammalia, Mysticeti, evolution, Oligocene, Miocene, Zealandia, Australia.

Felix G. Marx [felix.marx@monash.edu], Directorate Earth and History of Life, Royal Belgian Institute of Natural Sciences, Rue Vautier 29, Brussels 1000, Belgium; Department of Geology, University of Liège, Belgium; School of Biological Sciences, Monash University, Clayton, Vic., Australia; Museums Victoria, Melbourne, Vic., Australia. Erich M.G. Fitzgerald [efitzgerald@museum.vic.gov.au], Museums Victoria, GPO Box 666, Melbourne, Vic. 3001, Australia; Department of Life Sciences, Natural History Museum, London, UK; Departments of Vertebrate Zoology and Paleobiology, National Museum of Natural History, Smithsonian Institution, Washington, DC, USA. R. Ewan Fordyce [ewan.fordyce@otago.ac.nz], Department of Geology, University of Otago, 360 Leith Walk, Dunedin 9054, New Zealand; Departments of Vertebrate Zoology and Paleobiology, National Museum of Natural History, Smithsonian Institution, Washington, DC, USA. 
This is an open-access article distributed under the terms of the Creative Commons

Attribution License (for details please see creativecommons.org), which permits unrestricted use, distribution, and reproduction in any medium, provided the original author and source are credited.

Faris: Full text $(512.8 \mathrm{kB})$ ।

FaF Supplementary file $(2,037.2 \mathrm{kB})$ 